Canadian University Music Review

Canadian University Music Review

Revue de musique des universités canadiennes

\title{
The Busoni Network and the Art of Creative Transcription
}

\section{Marc-André Roberge}

Volume 11, numéro 1, 1991

URI : https://id.erudit.org/iderudit/1014831ar

DOI : https://doi.org/10.7202/1014831ar

Aller au sommaire du numéro

Éditeur(s)

Canadian University Music Society / Société de musique des universités

canadiennes

ISSN

0710-0353 (imprimé)

2291-2436 (numérique)

Découvrir la revue

Citer cet article

Roberge, M.-A. (1991). The Busoni Network and the Art of Creative

Transcription. Canadian University Music Review / Revue de musique des

universités canadiennes, 11(1), 68-88. https://doi.org/10.7202/1014831ar

All Rights Reserved (C Canadian University Music Society / Société de musique des universités canadiennes, 1991
Ce document est protégé par la loi sur le droit d'auteur. L'utilisation des services d'Érudit (y compris la reproduction) est assujettie à sa politique d'utilisation que vous pouvez consulter en ligne.

https://apropos.erudit.org/fr/usagers/politique-dutilisation/ 


\title{
THE BUSONI NETWORK AND THE ART OF CREATIVE TRANSCRIPTION*
}

\author{
Marc-André Roberge
}

Recent research in the field of early twentieth-century music and musical life in Germany and Austria has shown that Schoenberg, Webern, and Berg were not active in an vacuum but part of a wider cultural context which included composers such as (to mention only two names) Alexander Zemlinsky and Franz Schreker, and that this group of composers had links with numerous artists and writers. ${ }^{1}$ It is now possible to see them in a much wider perspective or, in other words, as part of a network. This idea can also be applied to a number of fascinating figures of the nineteenth and twentieth centuries whose music, for a variety of reasons, has long been neglected: namely, Liszt, Alkan, Busoni, Godowsky, and Sorabji-all of them, except for Sorabji, keyboard giants. ${ }^{2}$ Their contribution has been progressively rediscovered (or even discovered) in the last twenty years or so, as is evident in the explosion in the field of literature and discography. An indication of the existence of links between these composers is that, in most cases, anyone who plays, writes about, or simply listens to the music of one of these composers has also a strong interest in the music of the others. This would probably not be the case if they were not part of one and the same "family" of artists.

It is the purpose of this article to draw attention to the fact that a number of major figures in the history of piano music and transcription since the 1850s form a closely knit group, even though they may appear to many people to be isolated eccentrics who distinguish themselves by works which, in terms of length and virtuosity, often go far beyond anything in the standard repertoire and which, for these reasons, have remained the province of a few enterprising artists. The term

* This article is an expanded version of a paper read at the 1990 Conference of the Canadian University Music Society in Victoria under the title "The Busoni Network: Creative Transcription in the Works of Some Nineteenth- and Twentieth-Century Composers."

${ }^{1}$ Among the numerous publications that have appeared in the last fifteen years, one notes the proceedings of three symposiums (Kolleritsch 1976, 1978; Budde and Stephan 1980). Other bibliographical references, together with discographies, can be found in Roberge 1983a, 1986a, $1986 \mathrm{~b}$.

2 About Alkan, see Roberge 1984; about Busoni, see Roberge 1991; about Sorabji, see Roberge 1983b, 1988-89, and the contribution titled "Un tessuto d'esecuzioni: A Roster of Performances of Works by Kaikhosru Shapurji Sorabji" in the forthcoming collective volume edited by Paul Rapoport. 
"network", which describes "an interconnected or interrelated group"(Webster), provides a convenient label for a number of figures who have always been rather difficult to classify because they do not belong to the mainstream of musical activity and have consequently been often reduced to footnotes or passing mentions in musicological writing. Whether or not the neglect these composers suffered has been justified and whether or not the current interest in their music will last (topics which cannot be addressed within the scope of this article), it seems appropriate to attempt to group them in a meaningful way. A study of the links between composers, performers, and transcribers shows that they can be grouped logically around Ferruccio Busoni (1866-1924) and, to a slightly lesser extent, Kaikhosru Shapurji Sorabji (1892-1988).

The word "school" is used to describe a group of artists under a common influence, and thus refers to people who immediately follow a key figure. A network, on the other hand, can include not only a key figure and people on whom that figure exerted an influence but also some predecessors who shared similar attitudes to various aspects of musical activity and who can thus be linked to that figure and to other people who are interconnected. This explains why the "Busoni network," as will be seen later on, includes people as far removed form Busoni, chronologically speaking, as Johann Sebastian bach and contemporary performers still in their thirties. While it is true that the whole picture could be seen from a different angle by choosing another composer as the centre of the network, so many links point to Busoni that he clearly deserves this central position.

The Busoni network could include dozens of names if one were to take into account all the composers and pianists (whether or not they were pupils of Busoni) as well as the numerous musicians who were close to him and on whom his towering personality made a deep impression, or who are linked with him in one way or another: for example, Émile Bosquet, Gottfried Galston, José Vianna da Motta, and Isidor Philipp, to name but a few of Busoni's contemporaries who had an interest in the music of the other composers of the network. The net could be cast even wider to include editors and musicologists as well as disciples, friends, and admirers. However, it seems preferable to limit the number of names to avoid blurring the picture. For the purposes of this article, it will be useful to describe some of the relationships between the most important members of the network as a prelude to a discussion of an important common characteristic, namely, a profound interest in the transcription of other composers' works - or, more precisely, creative transcription, which will be illustrated using two short works by the two central figures, Busoni and Sorabji.

The rather dense chart shown below gives a good visual idea of the number of links between many composers and performers whose names are listed chronologically from top to bottom and arranged into four columns from left to right: 
(1) six Anglo-Saxon composers, either by birth or adoption; ${ }^{3}$ (2) Busoni himself and Sorabji, to whom most arrows point; (3) four composers who played an important role in the development of keyboard music during a period of two centuries; ${ }^{4}$ and (4) a dozen performers known as exponents of the music of one or more of the composers listed in the chart. The names within brackets should be seen so to speak as fringe figures in the network; they are included because of teacher-pupil relationships, which are an important channel for the transmission of an artist's heritage. The Busoni pupils, indeed, have been especially active and successful in keeping alive their master's memory.

The relationships between the musicians mentioned in the chart are of four types: (1) studies with Busoni or pupils of Busoni; (2) performances; (3) writings; and (4) transcriptions and editions of works. A few examples will be given here for each of these categories in order to illustrate the links. The Appendix contains biographical notes, with dates, and points to the various relationships.

Busoni, in an essay of 1910 entitled "Value of the Transcription," wrote that in 1894 he had become conscious of certain deficiencies in his playing and had begun the study of the piano again by taking as his guide the works of Liszt (Busoni 1957: 86). He was known throughout his career as the major exponent of Liszt's large-scale works, like the Transcendental Etudes and the Years of Pilgrimage, which he was bold enough to perform as a set. ${ }^{5}$ In the early 1900 s, he championed the works of Alkan, much to the annoyance of the Berlin critics; there is no record, however, that he ever played Alkan's masterpiece, the massive Twelve Etudes in the Minor Keys, Op. 39 (1857). ${ }^{6}$ Busoni passed on his preference for long and complex works to Egon Petri, his most celebrated pupil and disciple, who was the sole exponent of Alkan's Etudes before the upsurge of interest in his music in the 1970s, and of Busoni's large-scale works like the 70minute Concerto for Piano, Orchestra, and Male Chorus, BV 247 (1904) and the 30-minute Fantasia contrappuntistica, BV 256 (1910). ${ }^{7}$

${ }^{3}$ Grainger was born in Australia and settled in the United States in 1914; Dieren was born in Holland and settled in England at the age of twenty-five; Rawsthorne is English; Aplvor is an Irishman of Welsh parentage; Stevenson was born in England of parents of Scottish and Welsh descent but has been living in Scotland since 1952; and Sitsky is Australian.

${ }^{4}$ It will be noted that Bach, Liszt, and Alkan, who were all dead when Busoni reached any position of influence, are somewhat involuntarily included in the network; this is justified by the importance they have for many of the figures listed in the chart.

${ }^{5}$ Few pianists today - except may be those of the Busoni network-have enough stamina to present recital programs as substantial as Busoni's. For examples of such programs, see "Six Programs by Ferruccio Busoni Devoted to the Piano Works of Franz Liszt, October 31-December 3, 1911, Berlin, Germany" in Hinson 1987: 840-41.

6 The published score (Paris: Gérard Billaudot Éditeur, ca. 1970) consists of two volumes totalling 277 pages; a performance of the complete work lasts approximately 125 minutes.

7 Both Alkan's Etudes and Busoni's Concerto (which was written at the time of his interest in Alkan's music) stand as masterpieces in the production of their respective composers. Busoni's work, like Alkan's, coincidentally (?) bears the opus number 39. 

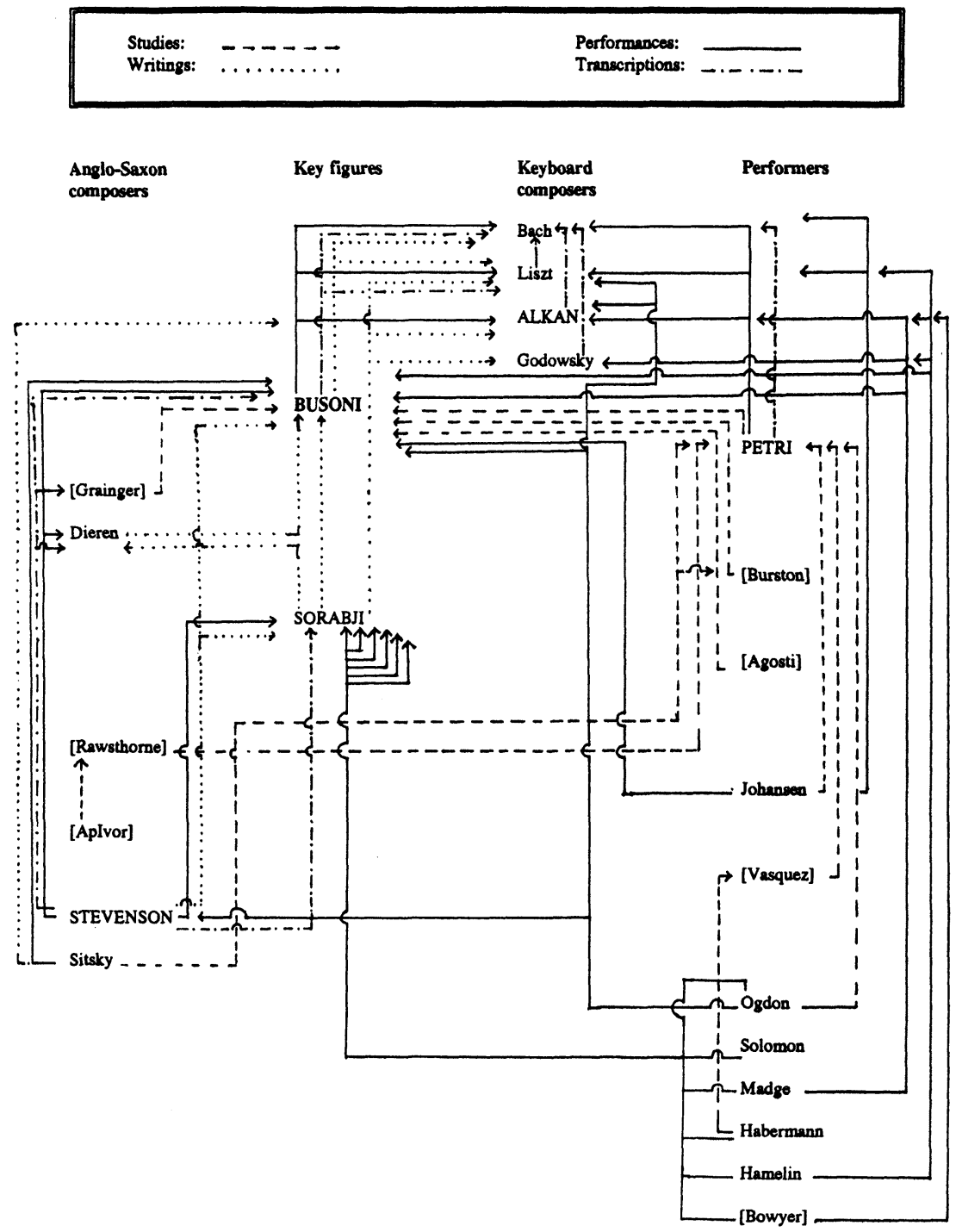

This tradition of playing large-scale and often neglected works continued with two pupils of Petri: John Ogdon, who made outstanding recordings of Busoni's Concerto, of the 50-minute three-movement "Concerto" from Alkan's Op. 39, and of Sorabji's massive four-hour Opus clavicembalisticum (1929-30); and 
Gunnar Johansen, who privately recorded most of Bach, Liszt, and Busoni on more than 100 discs. $^{8}$ Other exponents of large-scale works by composers of the network are Geoffrey Douglas Madge and Marc-André Hamelin, both of whom are among the few champions of Alkan, Busoni, Godowsky, and Sorabji. Among advocates of Sorabji, Yonty Solomon and Michael Habermann have been respectively pupils of Petri pupils Guido Agosti and Carlos Vasquez.

Shifting the emphasis to writing about music, one notes that Busoni wrote essays about Bach and Liszt and that the two collections of essays by Sorabji contain discussions of the music of Liszt, Alkan, Godowsky, Busoni, and van Dieren, who himself produced a large-scale essay about Busoni (in addition to being married to the pianist Frieda Kindler, who had been a pupil of Busoni). ${ }^{9}$ The Scottish composer and pianist Ronald Stevenson, in whose works homages to the composers he admires (needless to say, all members of the network) are countless, is an authority on the music of Busoni and has many articles about him to his credit. ${ }^{10}$ The Australian composer Larry Sitsky, who studied with Winifred Burston, herself a pupil of Busoni, as well as with Petri, wrote a substantial article about Alkan and a comprehensive book on Busoni's piano music (Sitsky 1974, 1986).

Turning to transcriptions and editions, it is of interest that Busoni arranged or edited several works by Bach and Liszt ${ }^{11}$ (who himself made transcriptions of works by Bach), that Petri made piano reductions of works by Busoni and edited with him the keyboard works of Bach, and that the Irish composer Denis ApIvor, who studied with Alan Rawsthorne, himself a pupil of Petri, made a transcription for orchestra of Busoni's Fantasia contrappuntistica. Finally, Ronald Stevenson once described Busoni as his "master in absentia" and said that he was attracted to his figure against all advice. Stevenson, who considers that Busoni "was the only composer-and still is-who has in his music embraced the whole range of European music from Bach to Schönberg,"12 is the author of a Prelude, Fugue and Fantasy on Busoni's "Faust" (1959) and of a grandiose Passacaglia on DSCH (1960-62), which, with its multiple figures, is a close relative of Busoni's Fantasia contrappuntistica and Sorabji's Opus clavicembalisticum, two works themselves sharing many parallels. ${ }^{13}$

${ }^{8}$ These discs began to appear in the 1960s under Johansen's own label Artist Direct Records. For more information about Johansen, see Corleonis 1986.

9 See Sorabji 1932, 1947. The essay by van Dieren was published as part of Down among the Dead Men and Other Essays (Dieren 1935: 20-101).

${ }^{10}$ Stevenson is the author of a forthcoming book titled Busoni: Aspects of a Genius (London: Toccata Press).

11 The 115 items listed in the section devoted to cadenzas and transcriptions in the thematic catalogue of Busoni's works (Kindermann 1980), 27 are transcriptions of Bach and 22 of Liszt.

12 See Stevenson 1971: 749 and the chapter titled "Magistri in absentia" in MacDonald 1989: 1929.

13 In this respect, see "Sorabji and Busoni Compared and Contrasted" in Benson 1987: 4-10. 
As a conclusion to this brief survey of the links between the members of the Busoni network, it may be appropriate to say a few words about the human element which often ties pupils to their master. New York Times critic Will Crutchfield recently wrote that "it is the destiny of Ferruccio Busoni's music to be perpetually revived and re-examined, never established in the repertory yet not forgotten either" (Crutchfield 1989: 21). This situation explains why a significant part of the literature published about Busoni before the late sixties consists of general assessments written by former pupils, friends, and admirers in order to convince readers of his importance. ${ }^{14}$ The most expansive of Busoni's admirers is surely Sorabji, witness this excerpt from his obituary of the composer:

Merely to see Busoni come on a platform but, above all, to stand in his presence and speak with him, was to feel oneself in the presence of an artistic and intellectual Titan like those divine men of the Renaissance, Da Vinci or Buonarotti-men so great that they cease any more to be human beings, and to whom the application of conventional human standards is like trying to measure the lightnings by an electric light meter. ${ }^{15}$ (Sorabji 1932: 21)

To be sure, such behaviour on the part of pupils and admirers was not limited to Busoni's entourage. It seems to have been common in Europe at that time for pupils to have for their master a boundless admiration that may seem exaggerated today, at least for non- Europeans. Berg and Webern, for example, had for their teacher Schoenberg, another dominant personality like Busoni, such a profound devotion that, in the 1910s, the two young composers seemed to live more for their master than for themselves. Berg, for instance, personally prepared the move of Schoenberg's belongings when he left for Berlin in 1911. ${ }^{16}$ Webern, on September 18 of the same year, wrote to his master: "Above everything, I would like to be with you. I picture the winter thus: I will be in whichever city you are and will make mainly [piano] reductions of your work" (Moldenhauer 1978: 149). Maybe we owe it to the devotion of such disciples that their masters were not forgotten before it was too late.

$* * *$

14 As Busoni scholar Antony Beaumont aptly put it, some of these authors "would employ a mystical language reeking of pretentiousness and sycophancy: his deficiencies were silently passed over" (Beaumont 1983: 119).

${ }^{15}$ See also the dedication of Sorabji's Variazioni e fuga triplice sopra "Dies irae" per pianoforte (1926), which, translated form the composer's slightly nonstandard Italian, reads: "To the holiest memory of the transcendental and superhuman genius of the divine master Busoni, with the supreme humility, faith, and devotion of the author" (Alla santissima memoria dell'ingegno trascendente $e$ sovrumano del divino Maestro Busoni, colla somma umiltà fede e devozione dello scrittore”). In fairness to Sorabji, it should be added that he later (ca. 1975) added in a note written on the title page of the work's manuscript that the dedication was "Exaggerated and excessive but in the XVIII[th] century flowery Italian tradition of dedications to some great person: of the [ ] Rossini's [ ] of St Peter (you know it in my sitting room) as the very falsesome dedication to 'Henry IX' the Cardinal Duke of York. You can lay it on yards thick in Italian!! In English it sounds just goddam silly!"

${ }_{16}$ See a letter from Berg to Schoenberg, dated September 22, 1911, in Brand, Hailey, and Harris 1987: 16-19; 18. 
Unlike numerous twentieth-century composers, six figures listed in the chartLiszt, Godowsky, Busoni, Grainger, Sorabji, and Stevenson-never hesitated in sacrificing part of their originality in order to let some of their works become, so to speak, a summary of the impact one or more composers had on them. Transcription was for them as fundamental as composition, and they did not see the former as a lesser activity, but as a different manner of expressing themselves. Even though their use of previously existing material may make them appear more like "contractors" than architects, the resulting works do not sound derivative because they are written, not by mere artisans, but by highly gifted creative minds who impose the stamp of their own style on the models they choose to build upon. Rather then being simple "manipulators" of other composes" styles, ${ }^{17}$ they are as creative as the Renaissance composers who, in their parody masses, made use of motives from works by other composers. ${ }^{18}$ In this respect, it may be worth recalling that Sorabji is not alone in comparing Busoni to a man of the Renaissance; this comparison recurs often enough in the literature to be considered a cliché.

Original composition and transcription are fused into a single unity in many of Busoni's works. Furthermore, the practice of reworking parts of previous works, sometimes written many years earlier, is an important aspect of his style, especially in his greatest work, the opera Doktor Faust, BV 303 (1916-24) ${ }^{19}$ In 1910, in his already quoted essay "Value of the Transcription," Busoni clearly indicated that, for him, composition and transcription were equivalent:

... notation is itself the transcription of an abstract idea.

The moment that the pen takes possession of it the thought loses its original form. The intention of writing down an idea necessitates already a choice of time and key. The composer is obliged to decide on the form and the key and they determine ... the course to be taken and the limitations. ... The idea becomes a sonata or a concerto; this is already an arrangement of the original.... The performance of a work is also a transcription. (Busoni 1957: 87-88)

A few examples will illustrate how Busoni hardly distinguishes not only between original composition and transcription but also between compositional styles, which results so to speak in a "rhapsody of styles." 20 These examples will also show that Busoni often went much beyond the "Bach-Busoni" style of the

17 This word was used with reference to Busoni by Waterhouse 1965-66: 79 who objects to Busoni being described as such.

18 This idea will be developed later in the article.

19 Approximately $15 \%$ of the total number of measures of this opera come from no fewer than 15 "satellite" works written from 1912 onwards. See the useful chart entitled "Überblick über die Verflechtungen innerhalb von Busonis Originalwerk ab 1890 (mit Hinweisen auf von Busoni benutzte fremde Vorlagen)" in Prinz 1970: between pp. 31 and 32; see also Arias 1984.

20 The expression "rhapsody of styles" seems to have been first used by Deliège 1987. 
transcriptions of Bach's organ works with which his name, unfortunately, has too often been associated. A series of four pieces for piano titled An die Jugend, BV 254 (1909), consists of: (1) a "Preludietto, Fughetta ed Esercizio," which was reworked a year later as the Sonatina No. 1, BV 257 (1910); (2) an arrangement of the D Major Prelude and Fugue from Book I of Bach's Well-Tempered Clavier, followed by a contrapuntal combination of both pieces; ${ }^{21}$ (3) a "Giga, Bolero e Variazione," based on works by Mozart;22 and (4) a transcription of two Caprices by Paganini, followed by a nontonal Epilogue. ${ }^{23}$ The huge Fantasia contrappuntistica for piano, which began as an attempt to complete the unfinished fugue from Bach's Art of Fugue, rapidly grew to a twelve-part work which, in addition to the completed quadruple fugue, contains: (1) a partly bitonal chorale prelude on a (so-called) Bach chorale (Allein Gott in der Höh sei Ehr) taken from " "Meine Seele bangt und hofft zu Dir...' (Choralvorspiel)," the third of the previously composed Elegies, BV 249 (1907); (2) an intermezzo followed by three variations and a cadenza; and (3) a return of the chorale prelude above a B-A-C-H ostinato in the lowest register and a final stretto.

A term often used in relation with Busoni is Nachdichtung, which means "free translation or arrangement," but whose much richer etymological meaning is "poem written after someone else." ${ }^{4}$ Nachdichtung very aptly describes those works which are based on foreign themes but are more original works than transcriptions, as are the Fantasia nach Bach, BV 253 (1909), or the Fantasia contrappuntistica. Another very fine example of such a work is the five-page Sonatina brevis "in signo Joannis Sebastiani Magni," BV 280 (1918), which Busoni himself, in a footnote on the first page, describes as a freie Nachdichtung of Bach's Fantasy and Fugue in D Minor, BWV 905, a work whose authenticity is dubious. ${ }^{25}$

21 This technique can also be found in two of Leopold Godowsky's 54 Studies after Chopin's Etudes (1899-1914), which consist of the simultaneous performance of two Chopin etudes; these are Nos. 47 (Op. 10, No. 5, with Op. 25, No. 10) and 48 (Op. 10, No. 11, with Op. 25, No. 3). It appears that combinations of the two A Minor studies from Op. 25 (Nos. 4 and 11) and of these studies together with the A Minor one from Op. 10 (No. 2) have remained unpublished (Nicholas 1989: 191).

22 The "Giga" is a reworking of the Gigue in G Major for piano, KV 574, and the "Bolero" is based on the finale of the third act of Le nozze di Figaro, KV 492.

${ }^{23}$ Busoni used Caprices No. 11 in C major and No. 15 in E minor.

24 The word also "implies a reconstruction of an original text in another language or style" (Beaumont 1985: 137)

25 The score is available in vol. 43, pp. 179-82, of the Bach-Gesellschaft edition of Bach's works. Busoni edited the work in 1917 and published it in 1920 as part of vol. 7 of his Bearbeitungen, Übertragungen, Studien und Kompositionen für Pianoforte nach Johann Sebastian Bach, vollständige und vervollkommnete Ausgabe (Leipzig: Breitkopf \& Härtel, 1920) and then in 1921 as vol. 16 of his 25-volume edition of Bach's keyboard works, issued under the title of Joh. Seb. Bach. Klavierwerke unter Mitwirkung von Egon Petri und Bruno Mugellini herausgegeben von Ferruccio Busoni (Leipzig: Breitkopf \& Hértel, 1894, 1914-16, 1920-21). The Fantasy and Fugue, in Busoni's edition (B 42 in Kindermann's catalog), is the initial part of a composite work which continues with the Andante in G Minor, BWV 969, and the Scherzo in D Minor, BWV 844. 
Example 1 (see below) shows the first nine measures of the original fugue in Busoni's edition, and Example 2 the end of Busoni's version of the Fantasy and the beginning of the Fugue. The Fantasy concludes with a canonic statement of an original motive of two falling diminished sevenths separated by a diminished fourth (E flat-F sharp-B flat-C sharp) which is first used as motto at the very beginning of the work. ${ }^{26}$ Busoni's modifications include octave transposition, voice exchange, chromatic alteration of motives as well as elimination of material and substitution or interpolation of new material. The reworking of the Fugue is even more radical. ${ }^{27}$ For instance, as can be seen from a comparison of Examples 1 and 2, the answer comes in $\mathrm{m} .3$ rather than in $\mathrm{m}$. 4 . Immediately after the answer's statement (m. 30), Busoni veers into twentieth-century counterpoint, thus leaving his model far behind. The remainder of this fascinating Nachdichtung, in which the diminished seventh motto is often heard in both its normal and inverted forms, has hardly any connection with the original except for the outline of the fugue subject. In mm. 81-82, what seems to be a standard cadence turns into a deceptive one with a last statement of the motto, which finally stabilizes in $\mathrm{m} .84$ on an A major chord which, however, does not quite sound like a dominant. ${ }^{28}$

In an outstanding dissertation on Busoni's piano music, Ulrich Prinz suggested that a central idea in Busoni's conception of composition is parody, whereby the word is used to describe the serious reworking of the musical material of another composition, as was the case in the parody masses of the sixteenth century (Prinz 1970: 26-31). The following parody techniques identified by Prinz are used in the examples already mentioned: (1) the use of a model as a skeleton and the paraphrasing of parts of the composition as in the "Giga, Bolero e Variazione" of An die Jugend; (2) the use of selected motives from the model as thematic material as in the Fantasy of the Sonatina brevis; and (3) the quotation of an independent section of a foreign work which is then freely developed as in the Fantasia contrappuntistica. Two other techniques, not used by earlier composers, can be identified: (1) the combination of two original or foreign works into a third, new work, which contains original insertions and developments, as in the "Paganinesco" of An die Jugend; and (2) the vertical combination of two foreign works, as in the "Preludio, fuga e fuga figurata" of the same work.

Another composer in whose production completely original works often start as transcriptions is Godowsky, whose rarely played 54 Studies after Chopin's Etudes (1894-1914) are among the most significant contributions to piano technique. In many of these studies, in which Godowsky develops the polyphonic, polyrhythmic, and polydynamic possibilities of the instrument to proportions

${ }^{26}$ See Beaumont 1985: 271 and Sitsky: 73-74 for hypotheses about the origin of this motto.

27 Both fugues contain 60 measures but are so different that one is in presence of two completely different works.

${ }^{28}$ The best recording of the work so far is by Paul Jacobs on Nonesuch H-71359 (LP, 1979). 

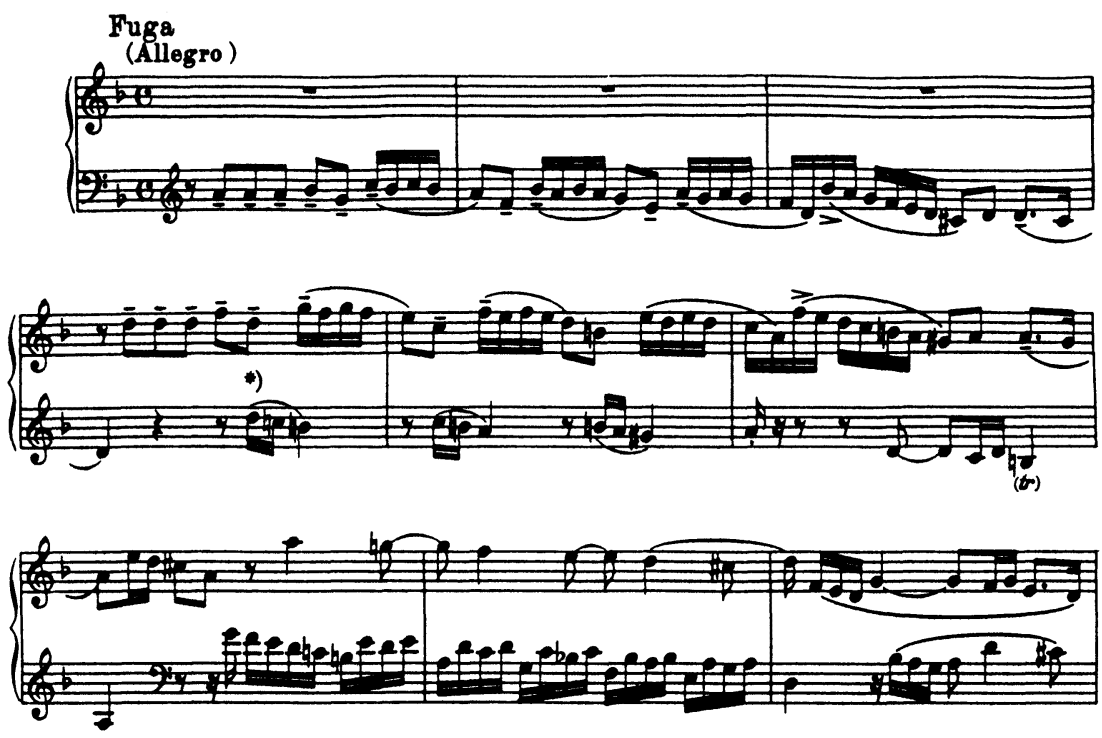

Example 1: J.S. Bach, Fantasy and Fugue in D minor, BWV 905: "Fugue," mm.1-9 (Busoni-Ausgabe). Copyright Breitkopf \& Härtel, Wiesbaden. Reproduced with permission.

hitherto unheard of, the polyphonic additions actually become so extensive that he rightly describes them as metamorphoses. The following words, which Sorabji wrote in his essay "Leopold Godowsky as Creative Transcriber," can easily be applied to Busoni:

The great transcriber expounds, enlarges and amplifies matter and thought that it has been left to him to discover and reveal ... and makes the original a point de départ for a great new creation. (Sorabji 1947: 63)

Busoni, of course, is not the only twentieth-century composer who has made use of the past in order to produce new works: Stravinsky is also a case in point, though Busoni precedes him by about ten years. In this postmodern era, a number of contemporary composers are increasingly looking to the past for inspiration. ${ }^{29}$ Among them, a remarkable figure is the Estonian Arvo Pärt (b. 1935), whose works remind the listener of the music of the Middle Ages yet fully belong to our era. Since synthesis of the old and the new seems to have become a viable

${ }^{29}$ See, for example, the Toccata (1977) for orchestra after Frescobaldi by Luciano Berio, the Hoquetus David (1969) after Machaut by Harrison Birtwistle, the Fantasy on Purcell's "Fantasia on One Note" (1974) by Elliott Carter, the Ancient Voices of Children (1970) by George Crumb (quotations from Bach and Mahler), the Eight Songs for a Mad King (1969) by Peter Maxwell Davies (quotations from Handel), and Telemanniana (1967) by Hans Werner Henze. For a substantial list of composers and works, see Watkins 1988: 657-60. 

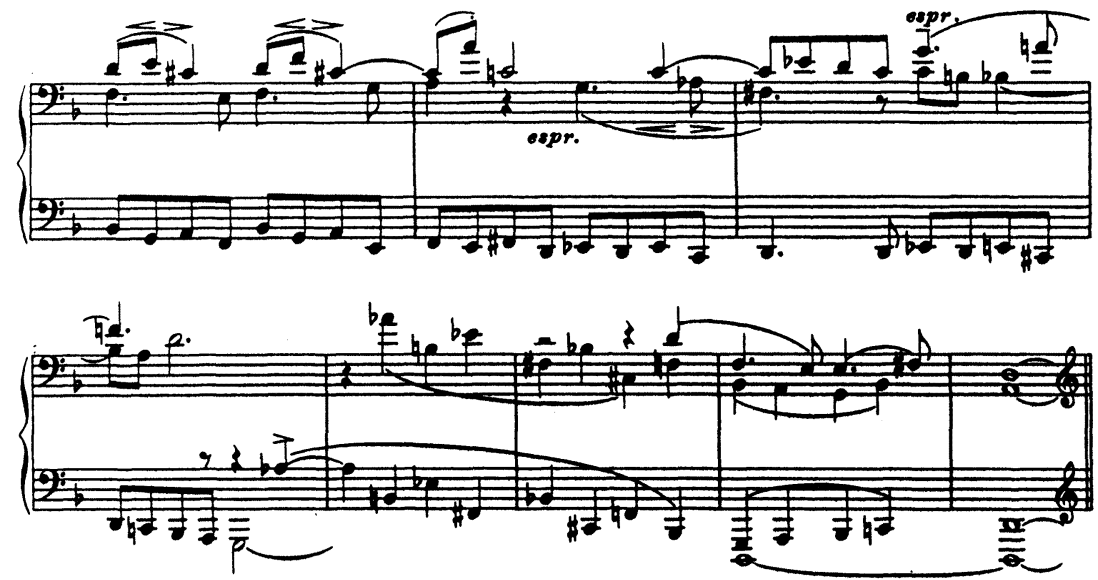

Poco più mosso, ma tranquillo
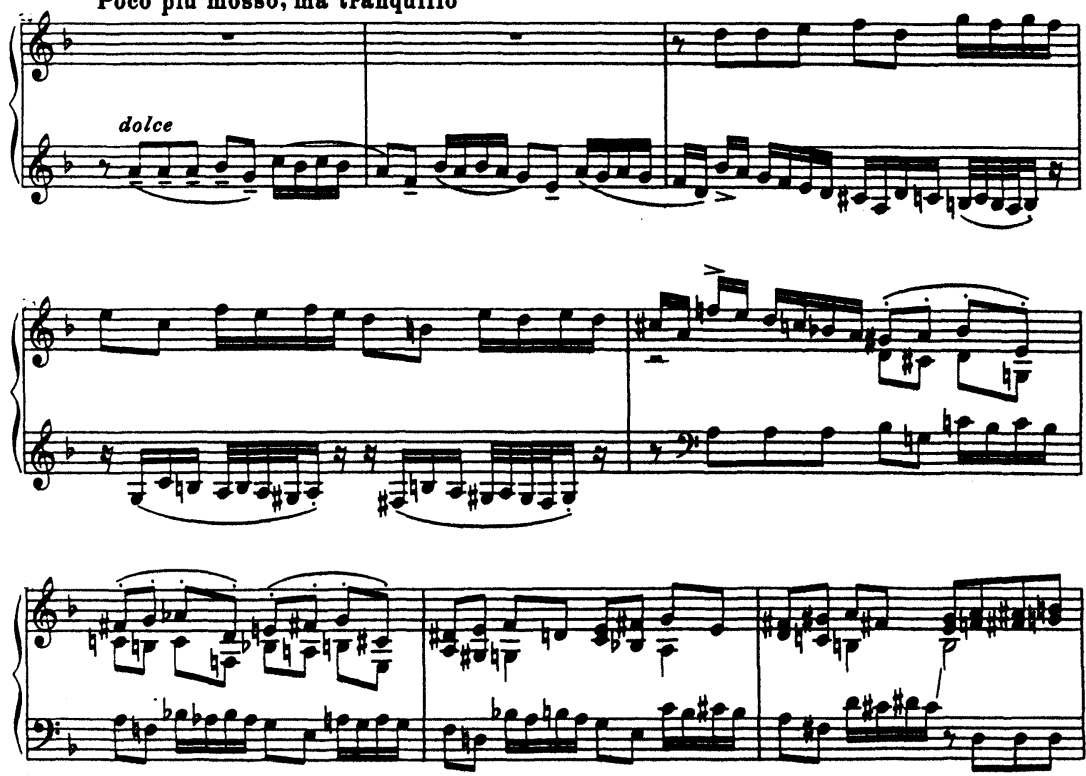

Example 2: Ferruccio Busoni, Sonatina brevis, mm. 18-33. Copyright Breitkopf \& Härtel, Wiesbaden. Reproduced with permission.

option, it comes as no surprise that the audience for Busoni's music is now increasing.

The other composer to be dealt with in some detail is Kaikhosru Shapurji Sorabji, the recently deceased British-resident Parsi who made a name for himself by 
forbidding performances of his gigantic works for forty years. He was also well known to readers of English periodicals for his panegyrical championship of Liszt, Alkan, Mahler, Busoni, Godowsky, Rachmaninov, Reger, Medtner, Szymanowski and van Dieren, and for his biting opposition to composers like Bartók, Stravinsky, Webern, and Hindemith ${ }^{30}$. Sorabji was a virtually self-taught composer and, like Ronald Stevenson after him, learned from "masters in $a b$ sentia," chief among which is Busoni, whom he met for the first and only time in November 1919 in London. He described this occasion, on which he played for Busoni his recently composed Piano Sonata No. 1, as "the most crucial moment of my musical youth." 31 His music is a fascinating synthesis of the impact exerted on his highly receptive mind by the works of the composers he admired most. The 10,000 pages he wrote contain examples of: (1) the flamboyant virtuoso style of Liszt, Alkan, and Rachmaninov, as in the 100 Transcendental Etudes (1940-44); (2) the highly refined polyphonic, polyrhythmic, and polydynamic writing of Godowsky; (3) the intricate counterpoint of Busoni and Reger, as in the double, triple, and quadruple fugues of the 248-page Opus clavicembalisticum; (4) the gigantism of Mahler, as in the 1001-page Messa alta sinfonica for eight vocal soloists, two choirs, and orchestra (1955-61); and (5) the sensuous Orientalism of Szymanowski, as in hothouse-style pieces like Nocturne: Jāmī (1928) and Gulistān: Nocturne for Piano (1940), and the exotic colour of Debussy and Ravel in works like the Fantaisie espagnole (1919). Following the example set by many of his favourite composers, Sorabji was strongly attracted to transcription. Writing about Godowsky's recastings and remouldings, he said that they evolved into "transcription-compositions" which

take on the aspect of new works built on and around an older core, much in the same way as the perpendicular splendours and glorious tracery of the later parts of Winchester Cathedral are build on around and out of the older Norman structure. (Sorabji 1947: 64-65)

Among Sorabji's reinterpretations of works by other composers, a superb example is the Pastiche on the Hindu Merchant's Song from "Sadko" by RimskyKorsakov (1922), which is part of a group of three Pastiches, the others being based on the Minute Waltz by Chopin and the "Habanera" from Carmen by Bizet. ${ }^{32}$

\footnotetext{
${ }^{30}$ In addition to the essays collected in Sorabji 1932 and 1947, Sorabji's thinking about music and musicians can be studied in his collected writings, chief among which are his articles for the English journals The New Age and The New English Weekly (Sorabji 1977).

${ }^{31}$ Quoted in Alistair Hinton's liner notes for the recording of the Piano Sonata No. 1 by Marc-André Hamelin (Altarus AIR-CD-9050), which reproduces Sorabji's typewritten account of that meeting.

${ }^{32}$ Sorabji's use of the word "pastiche" in these titles is incorrect. The word, when not applied to eighteenth-century opera, describes "a literary, artistic, or musical work that imitates the style of previous work" (Webster). Thus, properly speaking, a pastiche is a work written in the style of another composer, either as an academic exercise or in view of parodying his or her style. What Sorabji wrote is in no way a pastiche but rather a transcription or, even more precisely, a Nachdichtung. Other works of his based on foreign material are a transcription of the Chromatic Fantasy by Bach (1940), and concert transcriptions of the Rapsodie espagnole by Ravel (1945) and of the final scene from Salome by Strauss (1947).
} 

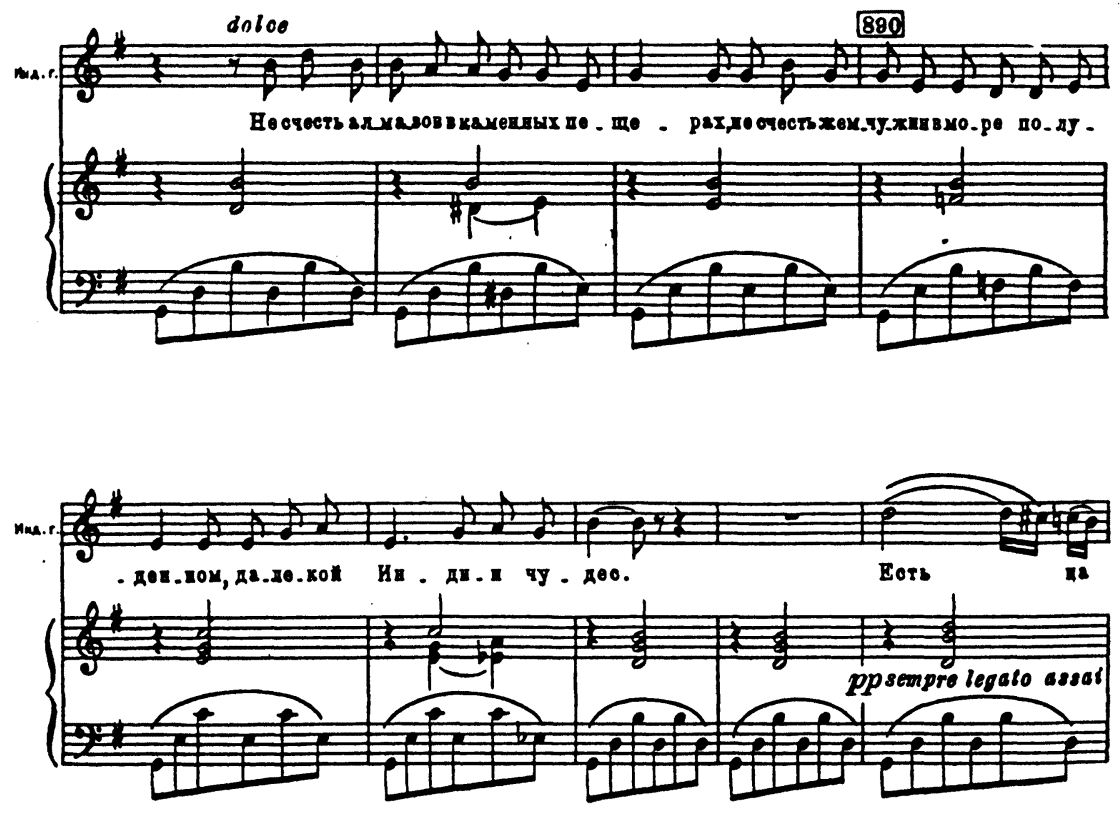

Example 3: Nikolai Rimsky-Korsakov, Sadko: scene 4, mm. 887- 95.

With the exception of a four-measure introduction, Song of India, as this excerpt is often called, is written throughout above a tonic pedal point and features a simple six-note rocking figuration played by the cellos, in most cases spanning a tenth (G-D-B), above which hovers a beautiful, sinuous melody sung by the tenor. ${ }^{33}$ This melody, which is shown in Example 3, gives way in m. 895 to a short chromatic descending motive which serves as main material (sometimes in expanded form) until the initial melody is heard again as a conclusion in $\mathrm{mm}$. 934-43.

One is fascinated by the extent to which Sorabji transforms the original material. Whereas Rimsky-Korsakov's version is written in G major, Sorabji's is in D-flat major, which is the key farthest removed in the circle of fifths. Example 4

33 This aria comes from the fourth scene of Rimsky-Korsakov's opera, which dates from 1894-96. The scene takes place at the Novgorod quayside, on the shores of Lake Ilmen. The singer Sadko, turning to the foreign merchants, requests them to sing ballads of their respective homelands to help him decide where best to sail in order to see all the marvels and wonders of the world. The scene comprises three songs, performed respectively by a Viking, a Hindu, and a Venetian merchant. The excerpt can be found in Nikolai Rimsky-Korsakov, Polioe sobranie sochineiy (Moscow and Leningrad: Gosudarstvennoe muzykal'ioe isdatel'stvo, 1948-), 6 b (1952): 177-83 (full score), 34 (1952): 28285 (vocal score). 

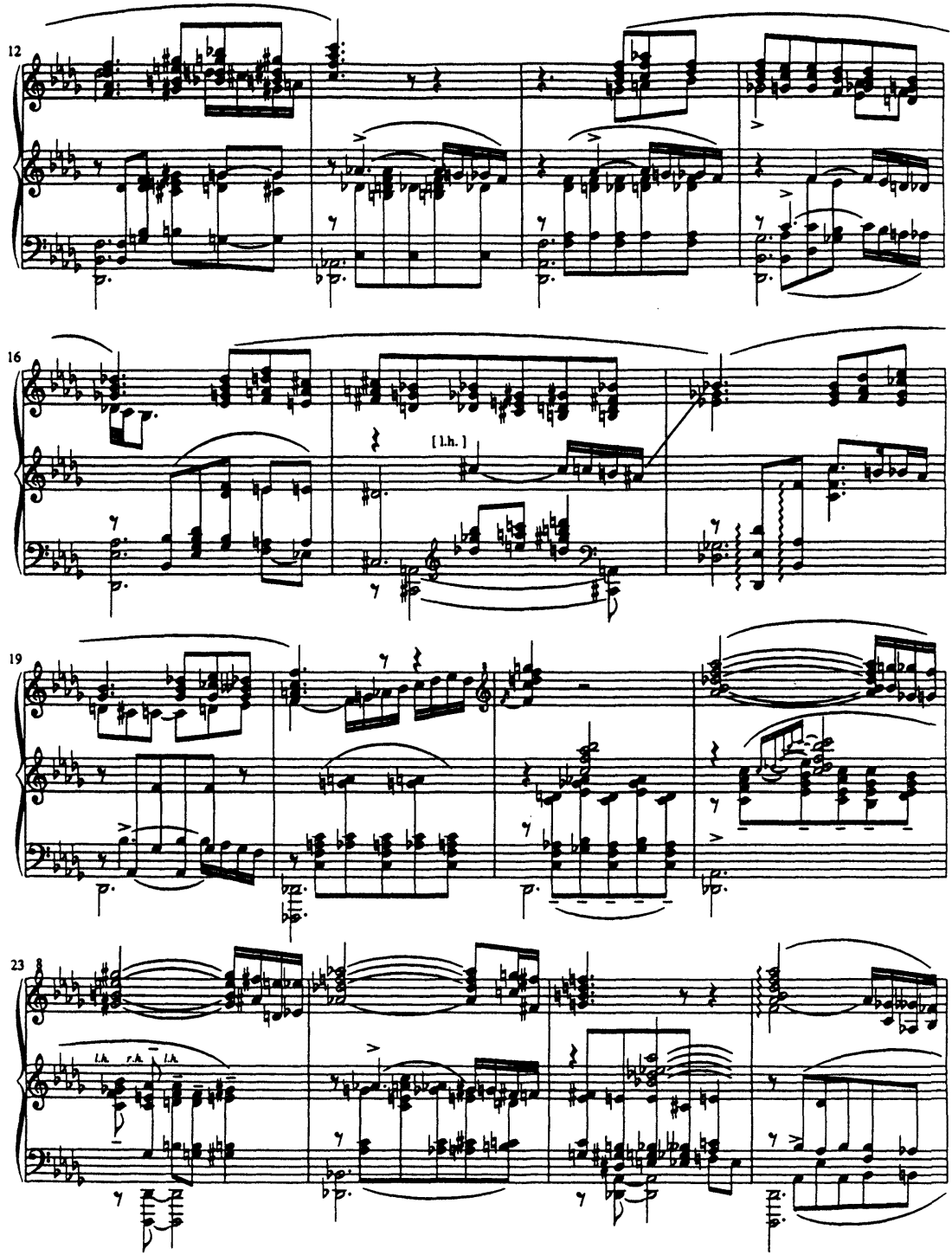

Example 4: Kaikhosru Shapurji Sorabji, Pastiche on the Hindu Merchant's Song from "Sadko" by Rimsky-Korsakov, mm. 12-26. Reproduced with the permission of the Sorabji Music Archive, Bath. 
reproduces mm. 12-26 of the Pastiche, which corresponds to the passage quoted in Example 3. ${ }^{34}$ The main theme appears in $\mathrm{mm} .14-20$, whereas the subsidiary descending chromatic motive is heard in mm. 12-15, 17, 19, 22-24, and 26; it is thus heard ahead of time with relation to the model. Throughout the work, almost every note of both melody and accompaniment is transformed -or rather, to use a word coined by an inspired writer, "sorabjazzed"-into a luscious chord (Corleonis 1984: 108). This results in a highly colourful harmony which heightens the exotic atmosphere and the beauty of the work far beyond anything that Rimsky-Korsakov could have imagined. Sorabji provides a thematic and polyphonic interest lacking in the original by almost constantly combining motives: for instance, he works together the descending chromatic motive with the main theme in $\mathrm{mm} .14-15,17$, and 19.35

Sorabji, rather than merely transcribing, creates a new work which is really his own, even though it contains the original within itself. One could easily apply to the Sadko Pastiche what he wrote with regard to some of the sonatas for solo violin and suites for cello by Bach to which Godowsky applied his unique gifts for creative transcription:

... these ... works are nightmares, grinning, dry, rattling skeletons of compositions, bloodless, fleshless, staring anatomies. Godowsky clothes them with flesh and blood and makes of them magnificent and indeed tremendous musical organisms having the sweep and grandeur, the profundity, solemnity and richness that is indeed associated with the greatest of Bach, but of which I can discern little or no trace in the bald bare sketches of the originals. (Sorabji 1947: 65)

This study of the most important links between a number of composer-pianists and pianist-composers should have made it clear that, far from being scattered figures, people like Liszt, Alkan, Busoni, Sorabji, and Stevenson are closely tied together and that, seen from our own perspective, Ferruccio Busoni, mostly, stands as the key figure. This status, while it proves nothing about Busoni's greatness as a composer, shows nevertheless that he is fascinating enough a figure to have shaped significantly the interests, the thinking, and the compositional and transcriptional attitudes and realizations of several highly gifted musicians of our century. Busoni is indeed one of the towering personalities in the history of modern music. The importance of creative transcription, which is much closer to composition than to arrangement, shows the existence of a

${ }^{34}$ Example 4 is taken from my critical edition of the work, which will be published by the Sorabji Music Archive (Bath, England). I would like to thank the curator of the Archive, Alistair Hinton, for kindly giving me permission to reproduce this excerpt.

35 The only recording of the work, by Michael Habermann, is available on Musicmasters MM 20019Y (LP, 1982 and CD 1988). 
tradition in twentieth-century music which should not be dismissed as negligible, even though it may run against the striving after originality which has long been fundamental for many creators of the twentieth century,. Now that this concern no longer has the importance it once had, one easily understand why the works of previously neglected or much too rapidly dismissed composers are becoming increasingly understood and appreciated for the riches they have to offer.

\section{APPENDIX}

\section{The Busoni Network: Biographical Notes}

[Guido Agosti (1901-89.] Italian pianist. Pupil of Busoni and teacher of Yonty Solomon.

[Charles-Valentin Alkan (1813-88). French composer and pianist. Author of the massive Twelve Etudes in the Minor Keys for Piano, Op. 39, which fill 277 pages in two volumes. Busoni, who ranked him among the five greatest composers of piano music after Beethoven, championed his music in Berlin in the early 1900s. Sorabji included an essay about him in Around Music.

[Denis ApIvor (b. 1916).] Irish composer of Welsh parentage. Studied composition with Petri pupil Alan Rawsthorne. His early work was influenced by van Dieren's music. Transcribed Busoni's Fantasia contrappuntistica for orchestra.

[Bach, Johann Sebastian (1685-1750).] German composer. Figured prominently in Busoni's piano repertoire. Many of his organ and some of his chamber works were transcribed for piano by Liszt, Alkan, Busoni, Godowsky, and Sorabji. His keyboard works were edited by Busoni and Petri.

[Kevin Bowyer (b. 1961).] English organist. Performed and recorded Sorabji's Organ Symphony No. 2 (2 CDs). Made the first recording of organ music by Alkan.

[Winifred Burston (1889-1976).] Australian pianist. Pupil of Busoni and teacher of Larry Stitsky.

Ferruccio Busoni (1866-1924). Italian composer and pianist active mostly in Germany. One of the greatest pianists of all times and a devoted exponent of the works of Bach and Liszt. Author of the prophetic Entwurf einer neuen Ästhetik der Tonkunst and composer of seminal works such as the Fantasia contrappuntistica and the opera Doktor Faust. Wrote several transcriptions and Nachdichtungen, mostly for piano.

Bernard van Dieren (1884-1936). Dutch composer. Married Dutch pianist Frieda Kindler, a pupil of his friend Busoni. Wrote a significant essay about Busoni in Down among the Dead Men. Sorabji included an essay about him in his book Mi contra fa.

Leopold Godowsky (1870-1938). Polish-born American pianist and composer 
whose consummate technique is reputed to have been unique in the history of piano playing. Developed the polyphonic, polyrhythmic, and polydynamic possibilities of the piano to proportions hitherto unheard of in his 54 Studies after Chopin's Etudes. Made piano transcriptions of some of the sonatas for violin and suites for cello by Bach in a style much similar to that used by Busoni in his transcription of the Chaconne for violin. Dedicatee of Busoni's transcription of Liszt's Campanella. Dedicated his contrapuntal arrangement of Weber's Aufforderung zum Tanz to Busoni. Sorabji included an essay about him titled "Leopold Godowsky as Creative Transcriber" in Mi contra fa.

Percy Grainger (1882-1961). Australian-born American pianist and composer. Piano pupil of Busoni. Some of his works were edited by Ronald Stevenson, with whom he corresponded.

Michael Habermann (b. 1950). American pianist. Studied with Carlos Vasquez, who was a pupil of Egon Petri. First pianist to be given permission by Sorabji to play his works in public. Gave several first performances of small and mediumsize works by Sorabji and made three recordings of his music. Dedicatee of Sorabji's Il gallo d'oro da Rimsky-Korsakov: variazioni frivole con un fuga anarchica, eretica e perversa.

Marc-André Hamelin (b. 1961). Canadian pianist. Reputed for his performances and recordings of large-scale nineteenth- and twentieth-century piano music, including works by Liszt, Alkan, Busoni, Godowsky, and Sorabji. Composed a Proaembulum to an Imaginary Piano Symphony (Homage to Kaikhosru Shapurji Sorabji, 1892-1988 (1989).

Gunnar Johansen (b. 1906). Danish-born American pianist and composer. Pupil of Egon Petri. Gave the first performance of Busoni's Ten Variations on a Prelude by Chopin. Recorded in his home the "complete" works of Bach (43 LPs), Liszt (51 LPs), and Busoni (7 LPs) as well as his own complete piano works (20 cassettes).

Franz Liszt (1811-86). Hungarian pianist and composer. Devoted about half of his creative output to transcription. Featured prominently in Busoni's recital programs. Busoni wrote a number of essays about him, edited his Etudes for publication in the first collected edition of his works, and transcribed several of his works.

Geoffrey Douglas Madge (b. 1941). Australian-born pianist active in Holland and known for his performances of contemporary works. Gave the first performance in fifty years of Sorabji's massive Opus clavicembalisticum. Recorded all of Busoni's significant piano music $(6 \mathrm{CDs})$ as well as the complete ChopinGodowsky Studies (4 CDs). Dedicatee of Sorabji's Passeggiata arlecchinesca sopra un frammento di Busoni (Rondò arlechinesco).

John Ogdon (1937-89). English pianist. Pupil of Egon Petri. Made his debut in 1958 by playing Busoni's Concerto for Piano, Orchestra, and Male Chorus, a work he subsequently recorded. Performed and recorded Alkan's three-movement "Concerto" from the Twelve Etudes in the Minor Keys, Op. 39, Stevenson's 
Passacaglia on DSCH (2 LPs) and Sorabji's Opus clavicembalisticum (4 CDs). Egon Petri (1881-1962). German pianist of Dutch descent. Pupil and life-long friend of Busoni, with whom he edited a 25-volume set of Bach's keyboard works. Prepared the piano scores of his master's major works. Dedicatee of Busoni's Bagatelles for violin and piano, of the second piece of the Elegies, and of his edition of Liszt's Heroic March in Hungarian Style. Recorded some of Busoni's original works and transcriptions of organ works by Bach. Received high praise from Sorabji for his performances of works by Busoni.

[Alan Rawsthorne (b. 1905).] English composer. Pupil of Egon Petri and composition teacher of Denis ApIvor.

Larry Sitsky (b. 1934). Australian composer. Pupil of Winifred Burston, who was a pupil of Busoni. Author of a substantial article about Alkan and of a major book about Busoni's piano music.

Yonty Solomon (b. 1938). South-African-born English pianist. First pianist to give official performances of works by Sorabji, starting in 1976. Gave several first performances of small- and medium-size works by Sorabji.

Kaikhosru Shapurji Sorabji (1892-1988). Parsi composer active in England. Known for his trenchant essays and reviews, many of which were collected in $\mathrm{Mi}$ contra fa: The Immoralisings of a Machiavellian Musician and Around Music, and for his dithyrambic championship of Busoni and other composers of the network. Much heard about for his large-scale works (which total approximately 10,000 pages in manuscript), some of which would last several hours in performance. Composer of the celebrated four-hour Opus clavicembalisticum, which shares many parallels with Busoni's Fantasia contrappuntistica. Dedicated his Sonatas Nos. 1 and 2 as well as his Variazioni e fuga triplice sopra "Dies irae" per pianoforte to Busoni and his Sequentia cyclica sopra "Dies irae" ex Missa pro defunctis to Egon Petri. Forbade performances of his works between 1936 and 1976.

Ronald Stevenson (b. 1928). Scottish composer and pianist of English origin. Studied orchestration with Busoni pupil and scholar Guido Guerrini. Indefatigable champion of Busoni, about whom he wrote several articles. Composed the massive Passacaglia on DSCH, which shares similarities with Busoni's Fantasia contrappuntistica and Sorabji's Opus clavicembalisticum, as well as the Prelude, Fugue and Fantasy on Busoni's "Faust". Wrote a Symphonic Elegy for Liszt and Le festin d'Alkan. Like Godowsky, combined two works by Chopin, namely, two waltzes, under the title Double Waltz. Published a new edition of the Canonic Studies by Bernhard Ziehn, whose theories of symmetrical inversion play an important role in Busoni's Fantasia contrappuntistica. Edited and/ or transcribed works by Busoni, van Dieren, Grainger (with whom he corresponded), and Sorabji. Dedicatee of Sorabji's Villa tasca (mezzogiorno siciliano)evocazione nostalgica.

[Carlos Vasquez (b. 19??).] Mexican (?) pianist. Pupil of Egon Petri and teacher of Michael Habermann. 


\section{REFERENCES}

ARIAS, Enrique Alberto

1984: "Pre-Existent Material in Busoni’s Doktor Faust," The Opera Journal, $17 /$ 3: 5-15.

BEAUMONT, Antony

1983: "Ferruccio Busoni: Composer and Bibliophile," Librarium: Zeitschrift der schweizerischen Bibliophilen-Gesellschaft, 26/2: 119-34.

1985: Busoni the Composer. Bloomington: Indiana University Press.

BENSON, Marjorie Mauslby

1987: "The Opus clavicembalisticum, by Kaikhosru Shapurgi [sic] Sorabji: An Analysis, with References to Its Model, the Fantasia contrappuntistica by Ferruccio Busoni." D.M.A. diss., The American Conservatory of Music.

BRAND, Juliane, Christopher HAILEY, and Donald HARRIS, eds.

1987: The Berg-Schoenberg Correspondence: Selected Letters. New York and London: W.W. Norton.

BUDDE, Elmar, and Rudolf STEPHAN, eds.

1980: Franz-Schreker-Symposion. Schriftenreihe der Hochschule der Künste, vol. 1. Berlin: Colloquium Verlag.

BUSONI, Ferruccio

1957: The Essence of Music and Other Papers, trans. from the German by Rosamond Ley. London: Rockliff Publishing Corporation, 1957. Repr. ed. New York: Dover Publications, 1987.

\section{CORLEONIS, Adrian}

1984: "Ferruccio Busoni: historia abscondita, b. Empoli (near Florence) 1 April 1966-d. Berlin, 27 July 1924," Fanfare, 7/3: 90-116.

1986: "A Birthday Greeting to Gunnar Johansen on His 80th," Fanfare, 9/2: 89. 96.

\section{CRUTCHFIELD, Will}

1989: "Paradox, Ambiguity and Ferruccio Busoni," The New York Times, January 22: sec. 2 , pp. 21,35 .

DELIÈGE, Célestin

1986: "Limit rationali di un'estetica della libertà," in Il flusso del tempo: scritti su Ferruccio Busoni, ed. Sergio Sablich and Rossana Dalmonte, 272-81. Quaderni di Musica/Realtà, no. 11. Milan: Edizioni Unicopli.

DIEREN, Bernard van

1935: Down among the Dead Men and Other Essays. London: Oxford University Press (Humphrey Milford). 
HINSON, Maurice

1987: Guide to the Pianist's Repertoire. 2nd ed. Bloomington and Indianapolis: Indiana University Press.

\section{KINDERMANN, Jürgen}

1980: Thematisch-chronologisches Verzeichnis der musikalischen Werke von Ferruccio B. Busoni. Studien zur Musikgeschichte des 19. Jahrhunderts, vol. 19. Regensburg: Gustav Bosse Verlag.

KOLLERITSCH, Otto, ed.

1976: Alexander Zemlinsky: Tradition im Umkreis der Wiener Schule. Studien zur Wertungsforschung, vol. 7. Graz: Universal Edition für Institut für Wertungsforschung.

1978: Franz Schreker: Am Beginn der Neuen Musik. Studien zur Wertungsforschung, vol. 11. Graz: Universal Edition für Institut für Wertungsforschung.

MACDONALD, Malcolm

1989: Ronald Stevenson: A Musical Biography. Edinburgh: National Library of Scotland.

MOLDENHAUER, Hans, and Rosaleen MOLDENHAUER

1978: Anton von Webern: A Chronicle of His Life and Work. London: Victor Gollancz.

NICHOLAS, Jeremy

1989: Godowsky: The Pianist's Pianist-A Biography of Leopold Godowsky. Wark, Hexam, Northumberland: Appian Publications \& Recordings.

PRINZ, Ulrich

1970: Ferruccio Busoni als Klavierkomponist. Stuttgart: Polyphoto Dr. Vogt.

RAPOPORT, Paul, ed.

199?: Sorabji: A Critical Celebration. Forthcoming.

ROBERGE, Marc-André

1983a: "Franz Schreker (1878-1934)," Sonances, revue musicale québécoise, 2/ 2: $2-8$.

1983b: "Kaikhosru Shapurji Sorabji, compositeur sui generis," Sonances, revue musicale québécoise, 2/3: 2-8.

1984: "Charles-Valentin Alkan (1813-88): un excentrique enfin pris au sérieux," Sonances, revue musicale québécoise, 3/3: 11-16.

1986a: "La redécouverte d'Alexander Zemlinsky: Schönberg avait-il raison?" Sonances, revue musicale québécoise, 5/2: 8-12.

1986b: "Franz Schreker: mise à jour," Sonances, revue musicale québécoise, 5/3: 21-23.

1988-89 "Kaikhosru Shapurji Sorabji (1892-1988)." Sonances, revue musicale québécoise, 8/2: 30-37. 
1991: Ferruccio Busoni: A Bio-Bibliography. Bio-Bibliographies in Music, no. 34. New York: Westport, Conn., and London: Greenwood Press.

SITSKY, Larry

1974: "Summary Notes for a Study on Alkan," Studies in Music (University of Western Australia), no. 8: 53-91.

1986: Busoni and the Piano: The Music, the Writings, and the Recordings. Contributions to the Study of Music and Dance, no. 7. New York, Westport, Conn., and London: Greenwood Press.

SORABJI, Kaikhosru Shapurji

1932: Around Music. London: The Unicorn Press. Repr. ed. Westport, Conn.: Hyperion Press.

1947: Micontra fa: The Immoralisings of a Machiavellian Musician.London: The Porcupine Press, 1947. Repr. ed. New York: Da Capo Press, 1986.

1977: "Kaikhosru Shapurji Sorabji: Collected Writings from Five Serial Publications." Compiled by Paul Rapoport and Kenneth Derus, microfilmed by the Photoduplication Department of the Joseph Regenstein Library, University of Chicago. Microfilm (one reel).

STEVENSON, Ronald

1971: "Composers Anthology: 3. Ronald Stevenson," Recorded Sound, nos. 42/43 (April-July), 747-57.

WATERHOUSE, John C.G.

1965-66: "Busoni: Visionary or Pasticheur?" Proceedings of the Royal Musical Association, 92: 79-93.

WATKINS, Glenn

1988: Soundings: Music in the Twentieth Century. New York: Schirmer Books; London: Collier Macmillan Publishers. 